\title{
ROLE OF INTERNAL AUDIT ON RURAL BANKS' FINANCIAL AND NON-FINANCIAL PERFORMANCE
}

\author{
Candy \\ Universitas Internasional Batam, Batam, Indonesia \\ Corresponding author: candy.chua@uib.ac.id
}

\begin{abstract}
This research aims to examine the effect of internal audit function on rural bank financial and non-financial performance. Data collection uses both primary and secondary data. Internal audit function and nonfinancial performance use questionnaires and 63 data were collected from 38 rural banks in Riau Islands Province. The financial performance uses return on asset (ROA) and return on equity (ROE) using the financial report published by Financial Services Authority of Indonesia. The respondents of this research are the director of rural banks. The analysis method uses Partial Least Square (PLS) to examine the outer and inner model. The result shows that the internal audit function positively affects both financial and nonfinancial performance. The rural bank, which has an established internal audit function, enhances the performance.
\end{abstract}

Keywords: Internal Audit, Bank Performance, Financial Performance, Non-Financial Performance, Rural Bank

\section{Introduction}

The growth associated development of an economy around the world depends mainly on the financial sector's performance. The banking sector may be a vital player within the financial industry and dominates the industry in most countries. Banks play a big role in ensuring efficient allocation of funds from idle sources to areas where funds are required. The financial sector's growth has been the foremost crucial impact on any country's economy for several years. Bank's performance is significant in driving to ensure sustainable growth within the future. Banks have realized that the audit function is essential in improving the bank's asset management efficiency, leading to an increase in the bank's financial performance. The audit function incorporates a vital economic role in the public's eyes by strengthening trust and trust in financial reports and statements created by public and private institutions. It additionally enhances the accountability provided by financial information (Mustari et al., 2020).

Internal audit is an independent, impartial assurance and assessment method for processing and expanding its activities. Internal audit helps the organization reach its objectives by developing systematic and controlled strategies for evaluating and developing the effectiveness of the organization's risk assessment, controls, and directive procedures (Ofei \& Owusu, 2021). Auditing includes a wide variety of activities, which serve different purposes. Traditionally, it has been an impact mechanism to assure that a government official or its ministry (internal audit) and an established legislative body (external audit), that public funds are received and utilized by appropriate and established laws and related regulations (audit compliance). The government's financial performance report is accurate and fair and is prepared from the underlying financial records, and represents its financial position (financial audit) (Asika \& Bonaventure, 2020).

An internal audit function is a form of governance that rural banks in Indonesia must implement in every business activity. Rural banks with a core capital of at least 50,000,000,000 rupiahs are required to form an internal audit work unit, while rural banks with a core capital of fewer than 50,000,000,000 rupiahs are required to appoint an executive officer to hold out the function of internal audit. The Board of Directors (BOD) should ensure the fulfillment of the number of human resources and appoint an official accountable for implementing the internal audit and being independent of other work units. The board of commissioners should ensure that the BOD follows abreast of audit findings and recommendations from work units or officials accountable for implementing rural banks' internal audit functions. Internal audit work units or executive employees are in charge of and responsible for the following activities:

1. Assist the director and BOD' duties in the direction of rural banks' operations, planning, implementing, and observance audit results.

2. Create analysis and assessment in finance, accounting, operations, and alternative activities by conducting an instantaneous examination and document analysis.

3. Distinctive all possibilities to enhance and increase efficiency within the use of resources and funds.

4. Offer recommendations for improvement and objective data for review of activities in any respect levels of management. 
The internal audit work unit or executive officer accountable for executing the function of internal audit is required to yield a report to the director, and board of commissioners with a duplicate to the BOD in charge of the compliance operate (Otoritas Jasa Keuangan, 2015).

Quality internal audit plays a significant part in accountability, transparency, and conserving public properties. Internal audit, auditor independence, and quality governance significantly affect bank financial performance. In contrast, the internal audit committee and meetings' size do not significantly impact bank performance. The results conjointly indicate that the use of automated internal audits in banks affects up financial performance (Hazaea et al., 2020). Bank management must ensure that internal audits are well understood and developed in all departments to be compatible with microfinance banks to ensure fraud prevention and control in microfinance banks. It is recommended that to ensure the internal audit is timetested, only a qualified and experienced accountant may be appointed as head of the internal audit department of a microfinance bank. External auditors must be paid well to maintain honesty in carrying out their duties. Management must ensure that internal audit provides a visual presentation to prospective auditors and prepares booklets and brochures describing the internal audit function. External checks, such as manual assessments, should be integrated into the banking system to facilitate entry to secure facilities on time, help minimize delays, and serve as a safeguard against possible collusion (Tapang \& Ibiam, 2019).

The study of Okello et al. (2019) shows a positive relationship between Kenya's commercial banks' internal audit and financial performance. It implies that the improvement of the audit function improves the financial performance of commercial banks in Kenya. A positive relationship also showed in the research of Ahmad (2018). Internal audit may be a orderly and autonomous examination of information, financial reports, account records, operations, and a corporation's performance to verify its legitimacy and fairness. It could be a wide term meaning the number of checks and controls meted out within the business to guarantee efficient work within the organization. It is considered an indication of the entire control system through management's vigilance and direction in conducting the business. It has become an important management tool to achieve adequate control by identifying deficiencies in management operations altogether industries, particularly the industry.

Internal audit is a function that aims to review the effectiveness and efficiency of organizational activities, ensure compliance with established regulations, evaluate risk management, and control internal systems. Internal audit is responsible to management in overall monitoring activities by assessing the effectiveness of control procedures (Bananuka et al., 2018). The study of Ndimitu et al. (2018) conducted by water supply companies in Kenya shows that internal audit positively affects company performance. A professional internal audit can ensure that company resources are used effectively and efficiently. Policeman's theory states that internal audit is responsible for finding, detecting, and preventing fraud. The internal audit design is carried out to protect company assets and assist in the verification process of accounting information for decision-making purposes. Research by Talab et al. (2018) shows that internal audit positively influences company performance. Internal audit plays a vital role in reducing information asymmetry between shareholders andimid management. Internal audit is also a monitoring mechanism that can reduce agency costs and improve company performance.

Alflahat (2017) concluded that internal audit has a positive effect on a company's performance. Internal audit control consists of the organizational plan, all approaches, and actions adopted in the business to maintain operational efficiency and promote compliance with defined managerial policies. This independent, objective, and consultative activity are carried out to improve risk management, control, and governance processes to achieve its goals.

Internal audit competence will improve company performance. Competencies that include knowledge and aptitudes empower internal audit to prepare and report audit results to the authorities professionally. The purpose of an internal audit is to contribute to the organization for the implementation of its responsibilities. Quality internal audits can help the board and management focus on their obligations to ensure that internal control is carried out appropriately and efficiently (Bello et al., 2017).

Matoke and Omwenga (2016) researched audit quality and financial performance in companies listed on the Nairobi Stock Exchange. The results showed that auditor size and auditor independence positively affect the company's financial performance. Several research results indicate that internal audit does not affect company performance (Muchiri \& Jagongo, 2017; Ejoh \& Ejom, 2014). An internal audit function does not affect the company's financial performance as seen from its profitability and return on investment. It is recommended that the internal audit function be independent and be carried out by competent staff (Muchiri \& Jagongo, 2017).

The research results of Farouk and Hassan (2014) show that auditor size and auditor independence also have a positive effect on company performance. Research by Alic and Rusjan (2010) shows that internal audit contributes to achieving business goals and positively influences company performance. The implementation of internal audit can provide benefits for companies like actions based on supported known non-conformities and suggestions given, well-organized documentation in terms of quality management systems, visibility of performance, and stable and reliable management processes for product and service quality assurance. Also, internal audit forms an independent, systematic, and objective approach to drawback identification and resolution. There are three hypotheses in this research as below: 
H1: The review of internal audit positively affects rural banks' performance.

$\mathrm{H} 2$ : The review of internal audit positively affects rural banks' financial performance.

H3: The review of internal audit positively affects rural banks' non-financial performance.

\section{Research Method}

The method of research is a quantitative approach by using both primary data and secondary data. The primary data uses questionnaires, and the secondary data collect data from rural bank financial report which published by Financial Service Authority of Indonesia. The respondents of the questionnaires are directors from rural banks in Riau Island Province in Indonesia. There were 63 data collected from 38 rural banks. One rural bank has up to three directors.

Internal audit as the independent variable uses three internal audit measurement components: the review of internal audit, regulatory compliance, and risk governance. Financial performance and non-financial performance as the dependent variables measure using the return on asset (ROA) and return on equity (ROE) (Menicucci \& Paolucci, 2016), and four components: quality, delivery of service, personnel development, and productivity (Rasid et al., 2014). This research also adds two control variables: bank size (Yang et al., 2018) and bank age (Florio \& Leoni, 2017).

\section{Result and Discussion}

The outer model test examines the validity of each indicator and the reliability of variables. Table 1 below shows the validity and reliability test result.

Table 1. Validity and Reliability Test

\begin{tabular}{llcc}
\hline \multicolumn{1}{c}{ Variable } & AVE & Cronbach's Alpha & Composite Reliability \\
\hline Bank Performance & 0.842 & 0.937 & 0.955 \\
\hline Internal Audit & 0.566 & 0.912 & 0.928 \\
\hline
\end{tabular}

Source: Processed Data (2021)

The inner model test examines the path coefficient. Table 2 shows the result of the path coefficient test.

Table 2. Path Coefficients

\begin{tabular}{lccc}
\hline \multicolumn{1}{c}{ Hypothesis } & Coefficients & P-Value & Result \\
\hline Internal Audit $\rightarrow$ Bank Performance & 0.442 & 0.004 & Accepted \\
\hline Internal Audit $\rightarrow$ Bank Financial Performance & -0.213 & 0.038 & Rejected \\
\hline Internal Audit $\rightarrow$ Bank Non-Financial Performance & 0.420 & 0.006 & Accepted
\end{tabular}

Source: Processed Data (2021)

The effect of internal audit on bank performance shows a coefficient of 0.442 with a P-Value of 0.004 . It means that the internal audit function has a significant positive effect on bank performance. Hypothesis 1 has been accepted. The result also showed in the research of Hazaea et al. (2020), Tapang and Ibiam (2019), Okello et al. (2019), Ahmad (2018), Talab et al. (2018), Alflahat (2017), Bello et al. (2017).

The effect of internal audit on bank financial performance shows a coefficient of -0.213 with a P-Value of 0.038. It means internal audit function has a significant negative effect on bank financial performance. Hypothesis 2 has been rejected. The effect of internal audit on bank non-financial performance shows a coefficient of 0.420 with a P-Value of 0.006 . It means internal audit function has a significant positive effect on bank non-financial performance. Hypothesis 3 has been accepted. The inner model test also examines the path coefficient of control variables. Table 3 shows the result of the path coefficient test.

Table 3. Path Coefficients (Control Variables)

\begin{tabular}{cccl}
\hline Direct Effect & Coefficients & P-Value & \multicolumn{1}{c}{ Result } \\
\hline Bank Age $\rightarrow$ Bank Performance & -0.347 & 0.011 & Negative \\
\hline Bank Size $\rightarrow$ Bank Performance & 0.005 & 0.966 & Insignificant \\
\hline
\end{tabular}

Source: Processed Data (2021)

The effect of bank age on bank performance shows a coefficient of -0.347 with a P-Value of 0.011 . In contrast, a coefficient of 0.005 with a P-Value of 0.966 showed bank size's effect on bank performance.

\section{Conclusion}

The result of this study showed that internal audit function in a rural bank could enhance its performance. However, it only shows a significant effect on non-financial performance. It does not show a significant effect on financial performance measured by return on asset (ROA) and return on equity (ROE). 


\section{References}

Ahmad, B. O. (2018). The effect of internal audit on organizational performance: An empirical exploration of selected Jordanian banks. Research Journal of Finance and Accounting, 9(14), 137-144.

Alaswad, S. A. M., \& Mile, S. (2016). Role of internal audit in performance of Libyan financial organizations. International Journal of Applied Research, 2(2), 352-356.

Alflahat, T. M. A. (2017). The impact of internal audit on organizational performance of selected Jordanian companies. International Journal of Multidisciplinary Research and Development, 4(8), 285-289.

Alic, M., \& Rusjan, B. (2010). Contribution of the ISO 9001 internal audit to business performance. International Journal of Quality and Reliability Management, 27, No. 8, 916-937. https://doi.org/10.1108/02656711011075116

Asika, R., \& Bonaventure, C. (2020). Effect of internal audit function on financial performance of commercial banks in Nigeria. International Journal of Advanced Academic Research (Social and Management Sciences), 6(7), 44-56. https://doi.org/10.46654/ij.24889849

Awdat, A. A. (2015). The impact of the internal audit function to improve the financial performance of commercial banks in Jordan. Research Journal of Finance and Accounting, 6, No. 3, 217-226.

Bananuka, J., Nkundabanyanga, S. K., Nalukenge, I., \& Kaawaase, T. (2018). Internal audit function, audit committees' effectiveness and accountability in the Ugandan statutory corporations. Journal of Financial Reporting and Accounting, 16(1). https://doi.org/doi.org/10.1108/JFRA-07-2016-0062

Bello, S. M., Ayoib, A. C., \& Zalina, Y. M. (2017). Investigating the relationship between internal audit quality and organisational performance of public universities in Nigeria. European Journal of Accounting and Finance Research, 5(6), 1-23.

Ejoh, N. O., \& Ejom, P. E. (2014). The effect of internal audit function on the financial performance of tertiary institution in Nigeria. International Journal of Economics, Commerce and Management, 2(10), 114.

Farouk, M. A., \& Hassan, S. U. (2014). Impact of audit quality and financial performance of quoted cement firms in Nigeria. International Journal of Accounting and Taxation, 2(2), 1-22.

Florio, C., \& Leoni, G. (2017). Enterprise risk management and firm performance: The Italian case. British Accounting Review, 49(1), 56-74. https://doi.org/10.1016/j.bar.2016.08.003

Hazaea, S. A., Tabash, M. I., Khatib, S. F. A., Zhu, J., \& Al-kuhali, A. A. (2020). The impact of internal audit quality on financial performance of Yemeni commercial banks: An empirical investigation. Journal of Asian Finance, Economics and Business, 7(11), 867-875. https://doi.org/10.13106/jafeb.2020.vol7.no11.867

Matoke, V. N., \& Omwenga, J. (2016). Audit quality and financial performance of companies listed in Nairobi Securities Exchange. International Journal of Scientific and Research Publications, 6(11), 372381. http://www.ijsrp.org/research-paper-1116.php?rp=P596000

Menicucci, E., \& Paolucci, G. (2016). The determinants of bank profitability: empirical evidence from European banking sector. In Journal of Financial Reporting and Accounting (Vol. 14, Issue 1). https://doi.org/10.1108/JFRA-05-2015-0060

Muchiri, N. W., \& Jagongo, A. (2017). Internal auditing and financial performance of public institutions in Kenya : A case study of Kenya Meat Commission. African Journal of Business Management, 11(8), 168174. https://doi.org/10.5897/AJBM2017.8267

Mustari, K., Rusibana, C., \& Nzamalu, A. (2020). Internal audit profession and financial performance in commercial banks in Rwanda. Journal of Advance Research in Business Management and Accounting, $6(10), 12-20$.

Ndimitu, P. N., Mwangi, C. I., Kisaka, S., \& Mwangi, M. (2018). Relationship between internal audit practices and performance of water service providers in Kenya. Archives of Business Research, 6(9), 91104. https://doi.org/10.14738/abr.69.5136

Ofei, E. F., \& Owusu, M. A. (2021). Assessing the moderating effects of corporate governance and government policy in the relationship between internal audit function and financial performance of banks in Ghana. International Journal of Innovative Finance and Economics Research, 9(1), 24-36.

Okello, S., Kirori, G. N., \& Ndiao, S. O. (2019). Financial performance of the banking sector in Kenya: The role of internal audit. Journal of Finance \& Accounting, 3(1), 29-50.

Otoritas Jasa Keuangan. (2015). Peraturan Otoritas Jasa Keuangan Nomor 4/POJK.03/2015 tentang Penerapan Kelola Bagi Bank Perkreditan Rakyat. https://www.ojk.go.id/id/regulasi/Documents/Pages/POJK-tentang-Penerapan-Tata-Kelola-bagi-BankPerkreditan-Rakyat/POJK 4. Penerapan Tata Kelola Bagi BPR.pdf

Rasid, S. Z. A., Isa, C. R., \& Ismail, W. K. W. (2014). Management accounting systems, enterprise risk management and organizational performance in financial institutions. Asian Review of Accounting, 22(2), 128-144. https://doi.org/10.1108/ARA-03-2013-0022

Talab, H. R., Manaf, K. B. B. A., \& Malak, S. S. D. B. A. (2018). Internal audit function, ownership structure and firm performance in Iraq. Journal of Engineering and Applied Sciences, 13(8), 2098-2102. https://doi.org/10.3923/jeasci.2018.2098.2102 
Tapang, A. T., \& Ibiam, O. (2019). Internal audit and financial performance of micro finance banks in Nigeria. International Journal of Social Sciences and Management Research, 5(4), 95-107.

Yang, S., Ishtiaq, M., \& Anwar, M. (2018). Enterprise risk management practices and firm performance, the mediating role of competitive advantage and the moderating role of financial literacy. Journal of Risk and Financial Management, 11(3), 1-17. https://doi.org/10.3390/jrfm11030035 